\title{
Sharing Our Stories The Work of Gary D. Schmidt
}

\author{
MARYYKATE SABLESKI
}

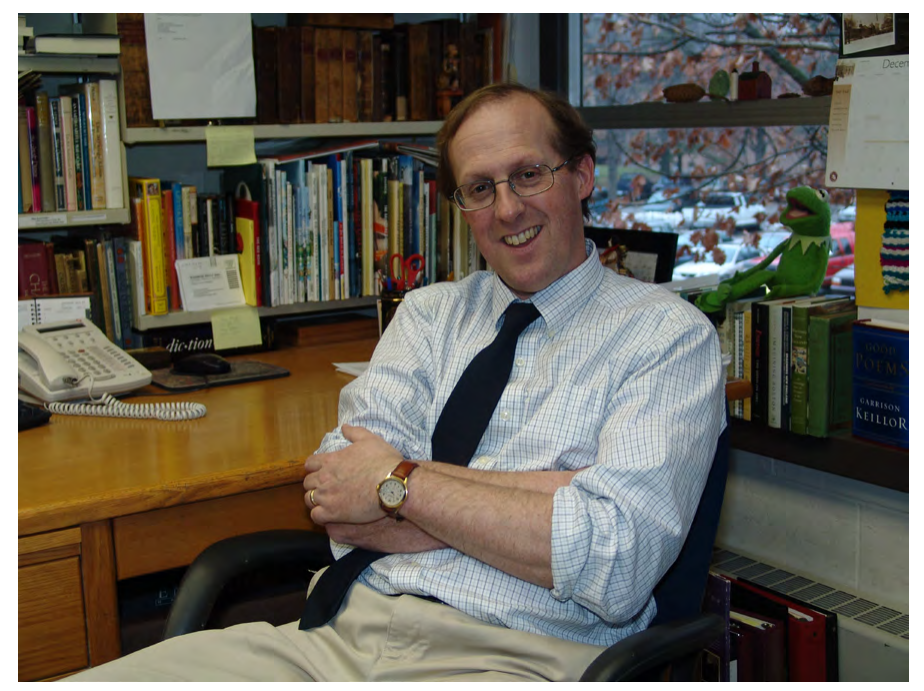

$\mathrm{S}$ haring a good book with a friend is one of the most fundamental experiences children need as they develop their identities as readers. In our libraries, we create spaces for children to find a great book, read it with support from others, and finally share those stories with their peers.

In my university classes, I create similar structures for my undergraduate students studying children's literature, and I model how to share books most effectively with children. As a class, we read several middle grade novels together, discussing the stories, sharing our interpretations, and brainstorming ways to share this literature with children.

Recently, we engaged in a study of the work of Gary D. Schmidt, and it ignited an interest and a passion in my students for the power his books can hold when shared with middle grade students. Small groups completed an in-depth project on this author's work, and three students reached out to Schmidt to see if he would complete a personal interview. He agreed, much to their delight, and they shared the completed interview in class.
The interview focuses on his book Okay for Now (2011). It also addresses his process and inspiration as a writer. I continue to use the interview in my classes as an example of the power of a mentor author to inspire and connect to student readers.

Schmidt is the author of many books for middle grade students, having won a Newbery Honor for The Wednesday Wars (2008), a Newbery Honor and a Printz Honor for Lizzie Bright and the Buckminster Boy (2005), and a National Book Award Finalist for Okay for Now (2011), among other honors and accolades for his work. His books are funny, engaging, and relatable to middle grade students.

Most recently, Schmidt contributed to a collection of essays, entitled 40 Stories Celebrating 40 Years of Star Wars: From a Certain Point of View (2017). His most recent novel for middle grade students is Orbiting Jupiter (2015). His picture-book biography, So Tall Within: Sojourner Truth's Long Walk Toward Freedom (2018), illustrated by Daniel Minter, departs from his work in middle grade novels to creating nonfiction for a younger audience.

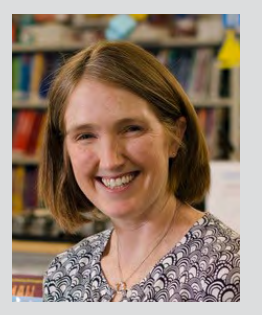

Mary-Kate Sableski is an assistant professor in the Department of Teacher Education at the University of Dayton, in Dayton, Ohio. She teaches undergraduate and graduate courses in children's literature and reading intervention. Her research interests include diversity in children's literature, struggling readers, and professional development. She can be reached at msableski1@udayton.edu. 
One of his most celebrated novels, Okay for Now, is the story of Doug Swieteck, a middle schooler struggling to find himself amidst his personal family struggles and the wider context of the world in 1968. The book is funny, heartbreaking, historically grounded, and, most of all, engaging to young readers who are also seeking to navigate their own path in life.

Studying Gary D. Schmidt's work helped my students see how connecting children to even one book in which they can see themselves can introduce a lifelong love of reading. My students learn through reading this interview how books, and deep connections to their authors, can serve as models of empathy and kindness. As the interview demonstrates, Schmidt's work resonates deeply with middle grade children and gives them a lens through which to learn about the world beyond them. (This interview has been slightly abridged.)

\section{What was your inspiration for Okay for Now?}

GS: The book began in the public library of Flint, Michigan. Flint has been called America's most violent city, mostly because the auto industry is gone and so there are no jobs, and when there are no jobs, there is despair and then violence-and we haven't even started on the water crisis there. So, I was in Flint, walking around that libraryit's an amazing place-looking at some of their holdings between gigs, and there was this low table that I came upon that had a glass case on top, and inside that, there was a book. A huge, huge book. It was a later edition of John James Audubon's Birds of America. If it was a first edition, that is a \$14 million book, one of the most expensive books in the world. It wasn't [a first edition], but it was an 1861 edition, so still worth half a million dollars.

So, when you think about it, here's this book sitting in a library in that city with no resources and really, really struggling to stay vital and alive. And yes, half a million dollars is a lot of money. So, I asked the librarians, "Why don't you sell this one?" And they said, "Because someday Flint is going to be back better than ever, and we want this for the new generation."

\section{That is such an awesome statement from a librarian.}

GS: I was thinking, wow, that is pretty noble. Then, when I was driving home from the library, there was a report on NPR about a school in Pennsylvania that in the 1930's had received a mural from N.C. Wyeth. This amazing mural was in the auditorium of the junior high and has been there since 1930 . They were trying to decide if they should keep this or if they should sell it. It's from one of America's most famous painters, this extraordinary painting that every junior high kid in this town has seen for eighty years. It's an original N.C. Wyeth and there really aren't that many left at all. So, should they sell this painting and get, I don't know, \$1.2 million or \$1.4 million and endow three teachers who would forever be endowed and not touchable by state budgets? That's pretty attractive. Or should they keep it?

Yes, being able to fund three teachers would be quite a statement from the school.

GS: But losing the painting is pretty awful. They fussed about it and thought about it, and finally they sold the painting; it's now in the hands of a private collector and is completely unavailable to anyone. But they got their three teachers. So, that really is the same story twice, a story about a work of art which one organization keeps and another organization sells. Both making hard decisions, but different decisions.

That was the beginning of Okay for Now. Here comes the kid, who comes to a library, who comes upon the most famous book in the world, and they are cutting it up to sell each page one by one-which is how these books get destroyed. He resolves that he wants one thing in his life that is whole and that's it. So, he goes for it: he tries to get all the missing pages back. And of course, he won't get them all back, but he will get some.

That is amazing. What a powerful story. What were the challenges of weaving those two stories together to write this book?

GS: Wow, I've never been asked that before. I suppose the voice had to be just right. He's a beat-up kid and he is hurt and he's in a beat-up situation and he is so angry - with good reason to be angry and bitter. But I wanted to create a book where you didn't get only his angry and cynical voice like an assault, but you want to get that tone across. He's also a kid that is unlikely to be very forthcoming and vulnerable with anyone.

So, to have a first-person narrator who doesn't want to be vulnerable presents a certain problem as well. Then, there are scenes in his life that he is going to tell which are pretty hard. The tattoo scene is a pretty hard scene. I wanted, I think, the voice to get all of that stuff to work, without him sounding ohso-sweet or without him sounding oh-so-angry, and that was probably the hardest thing. That is why there are all of those pauses where he is about to say something, and then he stops because he just wouldn't. An angry, hurt kid is not going to spill his guts to just anyone.

I would say you've been successful in crafting that voice! Doug is such a complex character.

GS: That is also why the tattoo scene is told somewhat removed from the reader's immediate experience. You hear about it, but you aren't there; you don't really see it because Doug won't express it so overtly. That is why the voice changes toward the end of the novel, where the kid who is so ready to pounce on anyone who questions him or who challenges him 
is the one called upon to provide comfort to someone who is really in desperate straits-and he steps up.

So, when you were younger and growing up, what were your favorite books to read, your favorite genre or author?

GS: There was a book called The Little World of Don Camillo, that came out right after World War II, set in Italy. It's probably the funniest book, the most poignant and painful book, I've ever read, by a writer named Giovanni Guareschi. It is still popular in Europe, but it has been out of print in America for forty years. It's this extraordinary story about a priest in a small town and his relationship with a Communist mayor. Obviously, they are completely at odds. It's just really a terrific book. I have it on my desk all the time at home, where every day I write. It's right there on my desk.

And the other books that I really, really loved are others that you never would have heard of either. They are from the 1920's, a collection called My Book House. It's a set of six books that later led to a twelve-volume set. That was probably America's first successful door-to-door sale of books. The woman who put together the six volumes, Olive Beaupre, literally went door-to-door to sell them. They were called My Book House because they were marketed, and I'm not making this up, in a little wooden house. The idea was that young readers were to grow up with them, as the material in each volume got harder and older. They were a collection of mostly Western European stories. I loved them. I thought they were fantastic. I loved the Horatio Hornblower books when I got a little older, but they are outdated now, though I still think they are really good.

Growing up, did you enjoy writing or did you ever keep a journal?

GS: I never kept a journal, and I still don't keep a journal. There are some people who love keeping journals. I hated it whenever I tried it. I still hate it, but I just don't do it all. I was not the kid who liked writing growing up. In our school in first grade, they used something called tracking. You were put into one of three tracks by the time we finished first grade. If you were in track one, you were going on to college and getting a great job. If you were in track two, you were probably going to be okay, maybe go on to college and have a good job. If you were in track three, you were the guy that was going to serve French fries at McDonald's the rest of your life. I was put in track three.

We were called the dumb kids, and the dumb kids got the least amount of attention when we really needed the most. By fourth grade I still was not able to read. There was a teacher in fourth grade, Miss Kabakov, who met me on the playground and who just liked me. She came in one day and took my hand and she said, "You need to get all of your stuff, you're coming with me," and I was like "Okay...." I have no idea how it happened, and my parents didn't even know how it happened, but she just took me into her classroom, and she had stuffed this desk with books, most of them way below grade level.
She was a track one teacher, and I was a track three student. She taught me to read in whatever breaks there were between other things. She would sit at my desk, and we would read Dr. Seuss and really young readers in fourth grade. So that's why I really don't have memories so much of really early reading, like picture-books and such. I just didn't do any of that. I just sort of started [reading] in fourth grade. For me, books were particularly odd and a dangerous thing. They could make you look like an idiot.

I like what you said about the neediest readers requiring the most attention to help them learn to read. Your books are certainly engaging and relatable to children who have experienced similar struggles. How did you think of a title for Okay for Now? What inspired you to come up with that kind of title?

GS: Okay, this is going to be disappointing to you. Are you ready? Most titles, particularly in fiction, most titles are not the author's titles. Of all of my books, I have maybe two or three titles that are actually mine. Most of the time, you send in [an idea], and it doesn't get accepted. An editor comes up with a list and you come up with a list, and you negotiate to try and figure out what the title is going to be. It's a long process. It's more about marketing than it is about aesthetics.

\section{What was the original title?}

GS: You know, I knew you were going to ask me that. I don't know, I don't even remember. Well, the Friday Library was one title I came up with, but that was just shot down immediately. Also Doug, but that turned out to be the title of a PBS cartoon. With titles, what happens is that I send in an idea, then they fly me out to Boston and I go up to the Houghton Mifflin offices and we work it out. For this novel, I went to the editor's office, and when they handed me the contract to sign, the title was Untitled Manuscript. I said, "Betsy, it does have a title," and she said, "No, that one really stinks." And we go from there. As I said, it's a really long process of working it out. The latest one is called What Came from the Stars, and that's my title, and the one before this was called Wednesday Wars, and they made that The Wednesday Wars over my objection.

Most of the books are not titled that way. So, Okay for Now is something that the editor came up with, and I sort of liked it. It sounds a little bit like a Jacqueline Woodson title, which is fine, but it seemed to fit. It seemed to work well with it, and he uses that phrase early on in the book, so that seemed to just all work pretty well. In the end, the characters are okay for now. I mean, you don't know what happens to Lil-though you will find out in a later book called Pay Attention, Carter Jones-and you don't know if the father is going to be on the right track very long, and you don't know if Christopher is going to stay okay, and you don't know if Lucas is going to be okay-though you'll find out about that in another later book called Orbiting Jupiter-but you do know that they are on the right path for right now. Maybe that's all that any of us can ever say. ¿. 